Article

\title{
Using InSAR Coherence for Investigating the Interplay of Fluvial and Aeolian Features in Arid Lands: Implications for Groundwater Potential in Egypt
}

\author{
Ahmed Gaber 1,*(D), Mohamed Abdelkareem ${ }^{2}$, Ismail S. Abdelsadek ${ }^{2}$ (D), Magaly Koch ${ }^{3}$ (D) \\ and Farouk El-Baz ${ }^{3}$ \\ 1 Geology Department, Port-Said University, Port-Said 42522, Egypt \\ 2 Geology Department, South Valley University, Qena 83523, Egypt; \\ mohamed.abdelkareem@sci.svu.edu.eg (M.A.); eng_ismailsayed@yahoo.com (I.S.A.) \\ 3 Center for Remote Sensing, Boston University, Boston, MA 02215-1401, USA; mkoch@bu.edu (M.K.); \\ farouk@bu.edu (F.E.-B.) \\ * Correspondence: ahmedgaber_881@hotmail.com
}

Received: 7 April 2018; Accepted: 23 May 2018; Published: 25 May 2018

\begin{abstract}
Despite the fact that the Sahara is considered the most arid region on Earth, it has witnessed prolonged fluvial and aeolian depositional history, and might harbor substantial fresh groundwater resources. Its ancient fluvial surfaces are, however, often concealed by aeolian deposits, inhibiting the discovery and mapping of potential groundwater recharge areas. However, recent advances in synthetic aperture radar (SAR) imaging offer a novel approach for detecting partially hidden and dynamic landscape features. Interferometry SAR coherence change detection (CCD) is a fairly recent technique that allows the mapping of very slight surface changes between multidate SAR images. Thus, this work explores the use of the CCD method to investigate the fluvial and aeolian morphodynamics along two paleochannels in Egypt. The results show that during wetter climates, runoff caused the erosion of solid rocks and the rounding of sand-sized grains, which were subsequently deposited in depressions further downstream. As an alternating dry climate prevailed, the sand deposits were reshaped into migrating linear dunes. These highly dynamic features are depicted on the CCD image with very low coherence values close to 0 (high change), while the deposits within the associated ephemeral wadis show low to moderate coherence values ranging from 0.2 to 0.4 (high to moderate change), and the country rocks show a relative absence of change with high coherence values close to 1 . These linear dunes crossed their parent's stream courses and dammed the runoff to form lakes during rainy seasons. Part of the dammed surface water would have infiltrated the ground to recharge the permeable wadi deposits. The alternation of fluvial and aeolian depositional environments produced unique hydromorphometrically trapped lakes that are very rare in arid regions, but of great interest because of their significance to groundwater recharge.
\end{abstract}

Keywords: InSAR coherence; fluvial and aeolian dynamics; groundwater resources; Egypt

\section{Introduction}

The Great Sahara of North Africa remains as one of the least understood regions of the Earth in terms of describing its depositional history and discovering its valuable resources. However, its northeastern part fared a little better, where studies confirmed the existence of significant fresh water resources that can be used for different land development plans [1-4]. This region was first systematically investigated by Ralph Bagnold, who pioneered a new era of desert exploration $[5,6]$ 
and provided much of the basic information on the desert in general and on the movement of dune sand in particular. Other contributions during the same period were made by Sanford [7] and Peel [8]. More recent and detailed geological studies of the Egyptian deserts were summarized by Said [9] and their regional geology was defined by Issawi $[10,11]$ and by the maps published in 1971 by the Geological Survey of Egypt.

Starting in the 1980s, space shuttle missions have been used for exploring large-scale and difficult-to-access areas along the eastern Sahara [12-30]. Space-borne images of the earth provide different levels of information that can be interpreted into considerable information of geomorphological, geological, and hydrological features. Radar sensors, such as the ones onboard of the space shuttle missions, have the ability to penetrate the dry sand sheet of the deserts and provide valuable information about the near-surface features, which is used as complementary information to that provided by visible and infrared sensors [14,28-30]. The Great Sahara, including the Egyptian deserts, are considered by many researchers as a type locality, which exemplifies the driest Earth environment. Radar imaging provided the first evidence for earlier pluvial periods in the eastern Sahara by imaging buried rivers and lakes as well as remnants of playa deposits [31,32]. Moreover, using the radiocarbon dating technique, Szabo et al. [32] demonstrated that the eastern Sahara experienced five pluvial episodes, which were interrupted by aeolian processes.

El-Baz [33] first proposed that the dune sand originated by fluvial erosion of the Nubian Sandstone, which was exposed throughout the southern part of the Eastern Sahara. Rounding of the grains must have occurred in turbid water as the particulate matter was repeatedly transported during humid phases in rivers and streams, which flowed generally northward. Fluvial erosion would have been very effective when that region received greater amounts of rainfall in the geological past. Even during recent times, increase rain along the equatorial belt resulted in the formation of lakes west of the Nile $[34,35]$. The sediment load of the fluvial channels would have been deposited in low areas (depressions) along the way. Such past fluvial activity would have also resulted in the accumulation of the underlying groundwater. As the climate became drier, the fluvial deposits were exposed to the action of the wind. The latter mobilized and sculpted the sand into various dune forms, depending on the amount of available sand and the prevailing wind directions. Aforementioned desert research works studied successive pluvial and aeolian processes using mainly time- and effort-consuming field mapping and relatively traditional remote sensing methods (change detection using optical sensors). However, in this work, the coherence products of the interferometry synthetic aperture radar (InSAR) is presented to investigate more accurately such fluvial and aeolian dynamics and make the field work more targeted for groundwater exploration activities.

The coherence products of the InSAR have been recently applied to the investigation of the fluvial and aeolian morphodynamics as this method is one of the most sensitive and powerful for mapping the surface changes [36-41]. Ullman et al. [40] investigated the use of coherence change detection (CCD) for the identification of surface disturbances, mass movements, and fluvial channel activity around the Damghan Playa in Iran, while Havivi et al. [41] have used the CCD method to analyze the dune dynamics along the southern coastal plain of Israel in both spatial and temporal domains. The CCD technique is based on the radar intensity and phase differences between two temporally different SAR images [42-47]. In arid environments, the surface changes of ephemeral streams and sand dunes is usually caused by both erosional and depositional processes and the movement of the sediment particles, all of which change the distribution of their respective radar intensity and backscattered response. Thus, the InSAR CCD technology is particularly appropriate for the identification and characterization of particles movements occurring on both changed and nonchanged surfaces [36,37].

This study aims at using the CCD technique for observing the fluvial and aeolian interplay actions at selected arid sites in the Eastern Desert (Wadi El-Matulla) and Western Desert (El-Gallaba Plain) of Egypt to investigate their potentiality for groundwater accumulation (Figure 1). While both study areas are located in watersheds draining into the River Nile, their morphostructural settings are quite 
distinct. They were selected to investigate whether CCD techniques are capable to unravel fluvial and aeolian processes under different geo-environmental conditions.

\section{General Setting of the Study Area}

The Eastern Desert of Egypt is bounded by the Red Sea in the East and the River Nile in the West and is characterized by its high relief (Red Sea Mountains) and well-dissected landscape depicting numerous surface drainage patterns. These ephemeral wadis can be classified into two main groups depending on their flow directions: the first group flows toward the Nile and the second flows toward the Red Sea [48]. Wadi El-Matulla, which is located between longitude $32^{\circ} 48^{\prime} \mathrm{E}$ and $34^{\circ} 20^{\prime} \mathrm{E}$ and latitude $25^{\circ} 25^{\prime} \mathrm{N}$ and $26^{\circ} 20^{\prime} \mathrm{N}$, fans out from the Red Sea Mountains and runs toward Qift City along the Nile (Figure 1). It is considered by the Egyptian Government as one of the most important wadis with potential for development. Thus, Wadi El-Matulla has been selected as a case study in this research work to investigate its fluvial and aeolian interactions to locate potential areas for groundwater resources development and help the Egyptian Government to achieve its megaproject named the Golden Triangle Project. The watershed of Wadi El-Matulla is covered by the basement complex on its eastern wadi side and by Cretaceous/Tertiary sedimentary rocks that are unconformable with the underlain basement complex on its western wadi side, as well as the Pliocene-Pleistocene deposits cover the lowest relief wadi courses [49] (Figure 2).

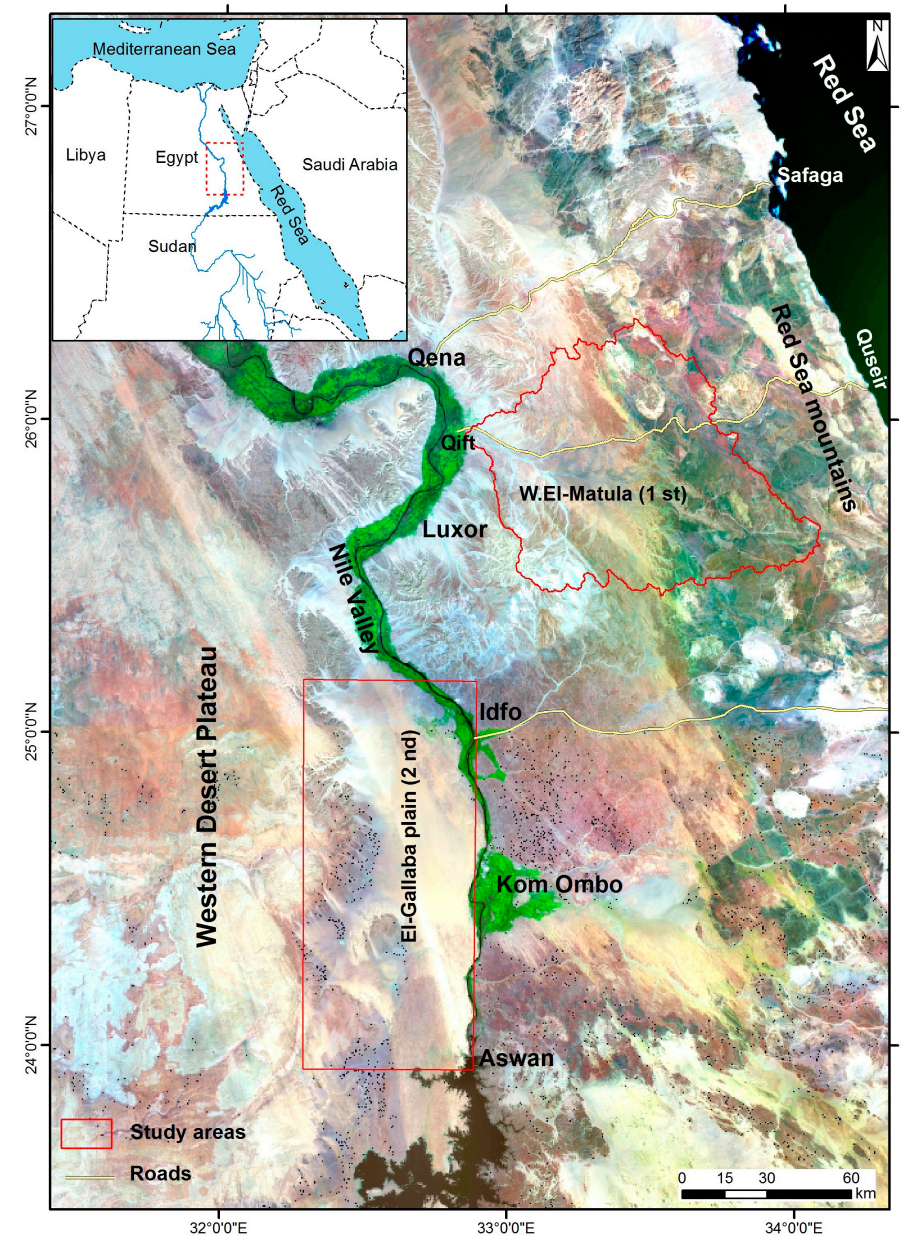

Figure 1. Location map of the study areas: Wadi El-Matulla (1st) in the Central Eastern Desert and El-Gallaba Plain (2nd) in the Western Desert of Egypt. The Nile River represents the dividing line between the two deserts, which show marked contrast in vegetation (depicted in green) and geological setting. 
The El-Gallaba Plain, which is a part of the Western Desert of Egypt, has been selected as the second case study to investigate fluvial-aeolian interplay features. It is located southwest of Wadi El-Matulla and west of Aswan City and is essentially covered by foreland sediments that range from Cretaceous (Nubian sandstone) to Pleistocene (gravels and sand). El-Gallaba Plain is bounded by the present River Nile on the east side and the Calcareous Sin El-Kaddab Plateau on the west side (Figure 1).

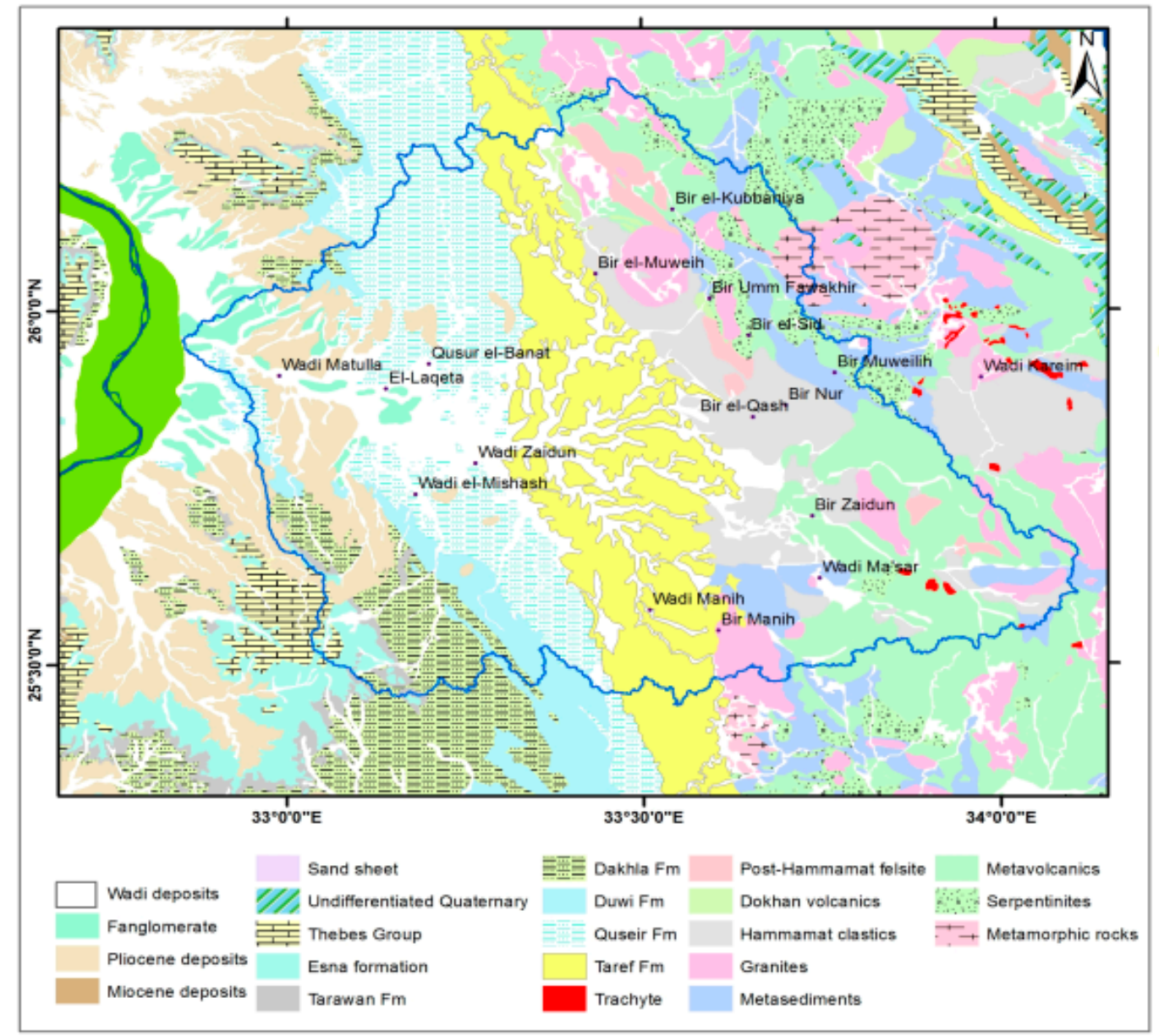

Figure 2. Geologic map of Wadi El-Matulla in the Central Eastern Desert of Egypt (after Conoco [50]). The yellow color shows the spatial distribution of the Taref Formation, which is the main source of sand that has been eroded by fluvial processes and reshaped as linear dunes by the wind actions.

\section{Data and Methods}

In this research work, four optical Sentinel-2 images, two covering Wadi El-Matulla (12 December 2016; and 17 December 2017) and two covering El-Gallaba Plain (12 December 2016, and 27 November 2017), were selected and processed using standard image processing techniques, including image enhancement and change detection method using the conventional single-band image subtraction. For the latter method, band 8 with $834 \mathrm{~nm}$ wavelength and $10 \mathrm{~m}$ spatial resolution was selected in order to detect the recent surface changes along the studied areas by subtracting the recent image dated December 2017 from the older one that was dated November 2016. In addition, high-resolution Google Earth images were used to provide better visual details of specific surface features detected on Sentinel-2 data in order to visually interpret them and compare them with the results obtained from processing the SAR data. Optical images were used to detect and clearly depict the sand-covered areas (aeolian processes) and their changes before comparing them with the results 
obtained from the CCD method. Wind directions were defined based on previous works and used together with field data from meteorological stations to confirm that the sand dunes patterns were indeed following the reported wind directions and controlled by the subsurface structures and local topography [51,52].

Radar images have been utilized in previous works along the Eastern Sahara to reveal locations of sand-buried courses of ancient rivers and streams [30,53-55]. However, in this work, four Sentinel-1 radar images with the Vertical-Vertical (VV) polarization covering the study areas (two for each) were selected to match the same acquisition dates as the optical Sentinel-2 images (16 September 2016, and 28 December 2017, for Wadi El-Matulla and 28 September 2016, and 28 December 2017, for El-Gallaba Plain). Further, the interferometric wide (IW) swath mode and single look complex (SLC) product format were used to perform the coherence change detection (CCD) using both the power and phase differences. This technique measures the changes in phase and intensity between two interferometric SAR images for the same area, but acquired at different times. In this study, the complex coherence maps were derived for the Wadi El-Matulla and El-Gallaba Plain to detect any surficial change patterns that are related to active aeolian and fluvial processes. Interferometric coherence $(\gamma)$ of two complex SAR images can be defined as follows, according to [56]:

$$
\gamma=\frac{\left|\sum_{k=1}^{N} f_{k} g_{k}^{\star}\right|}{\sqrt{\sum_{K=1}^{N}\left|f_{k}\right| 2 \sum_{K=1}^{N}\left|g_{k}\right|^{2}}}, 0 \leq \gamma \leq 1
$$

where $(\gamma)$ is the absolute value of the coherence at a certain pixel, $f_{k}$ and $g_{k}$ are the complex SAR images, and $g_{k}{ }^{*}$ is the complex conjugate of the other image. $N$ is the estimated window size. The coherence has values ranging between 0 and 1 . When the target has not changed over time, the coherence is close to 1 , and if there is a change, the value will be close to 0 [47,57]. The Sentinel- 1 mission is the European Radar Observatory for the Copernicus joint initiative of the European Commission (EC) and the European Space Agency (ESA). The sensor sends and receives signals in C-band with Vertical-Vertical (VV) and Vertical-Horizontal (VH) polarization and operates at a center frequency of 5.4 GHz. Several Sentinel-1A data covering Wadi El-Mattula and El-Gallaba Plain in a single look complex (SLC) format were downloaded free of charge from the website [58].

The downloaded Sentinel-1A (S1A) products were processed using the Sentinel Application Platform (SNAP) software (version 6.0) provided by the European Space Agency (ESA) in order to perform the following corrections and enhancements: multilooking and terrain corrections as well as estimating the CCD and phase differences. Before performing the coherence step, the subswaths of the SLC images were split and debursted separately to generate the coherence images. Finally, the obtained coherence maps were multilooked and projected by performing the terrain correction with a digital elevation model (DEM) acquired from the Shuttle Radar Topography Mission (SRTM) with Universal Transvers Mercator (UTM) coordinates system of datum World Geodetic System 1984 (WG84) and zone 36.

In addition, the Digital Elevation Model (DEM) data of the Shuttle Radar Topography Mission (SRTM) were used for extracting the surface drainage networks as well as the watershed boundaries. Fluvial channels along the selected study areas were mapped and compiled in a spatial database using GIS software. This was done by employing surface flow routing based on the eight direction (D-8) flow algorithm of Jenson and Domingue [59] and a hydrology module of a spatial analyst in subsequent steps including filling sinks, flow direction, flow accumulation, and stream delineation steps to extract the stream network [60,61]. Moreover, field observations at some selected sites were carried out to validate the fluvial and aeolian depositional activities extracted from the processed remote sensing data. 


\section{Results}

To fully recognize and understand the interplay of water and wind processes along the two selected case studies, features resulting from each process needed to be identified first. Thus, it was necessary to first establish the fluvial regime, and second, understand the wind regime and its effect on the fluvial regime, before investigating both regimes and their potential influence on groundwater accumulations in water-poor regions.

Based on the results of the SRTM analysis, the elevation of the Wadi El-Matulla ranges from 62-1047 m (a.s.1.) and its present main course has high runoff westward to the River Nile at the Qena bend with a stream order of 7 (Figures 3 and 4). During sporadic showers, it receives a great part of its supply from a number of tributaries coming out from many gorges (Wadi Zidun and Wadi Hammamat) in the Red Sea highlands [62]. Wadi El-Matulla, similar to the rest of the Sahara, revealed past pluvial conditions as the climate was interrupted by several moist Pleistocene episodes. This allowed deposition of the fluvially weathered sands from the Taref Formation (Figures 2 and 3 ) in depression areas found along the downstream reaches (Figure 3). Evidence of heavy rainfall intervals are still preserved as marks of fluvial action along the Wadi El-Matulla basin through the remnants of the washed-out Taref Formation, which directly capped the basement rocks and is considered as the main source of the wind-blown sand (Figures 4c and 5).

The wind regime of the Eastern Sahara in general trends in a well-defined pattern that flows southward from the coastal zone of the Mediterranean Sea. Weather satellite images helped greatly in deciphering the details of this regional pattern [63]. It is interesting to note that the same pattern was first suggested by Bagnold [6]. Surface wind data were obtained from 42 meteorological stations in Egypt [64]. Summaries of wind rose diagrams and sand-drift potential resultants agree with the basic pattern of a net southward direction of sand transport [65]. Thus, the sand-carrying wind in Egypt moved southward during most of the year, except where it was locally affected by topographic prominences [66].

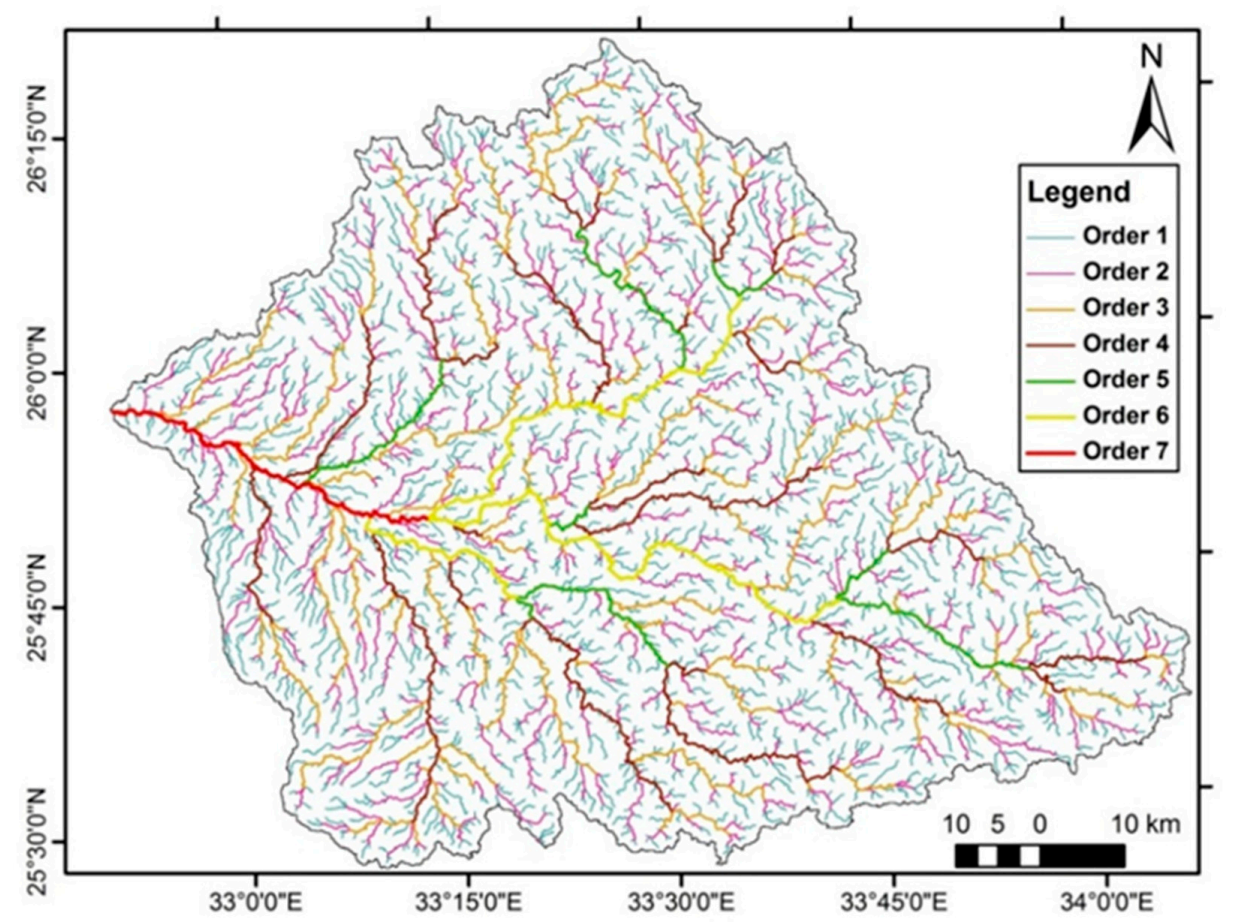

Figure 3. The stream orders of Wadi El-Mattula, which were derived from the Digital Elevation Model (DEM) data of the Shuttle Radar Topography Mission (SRTM). 


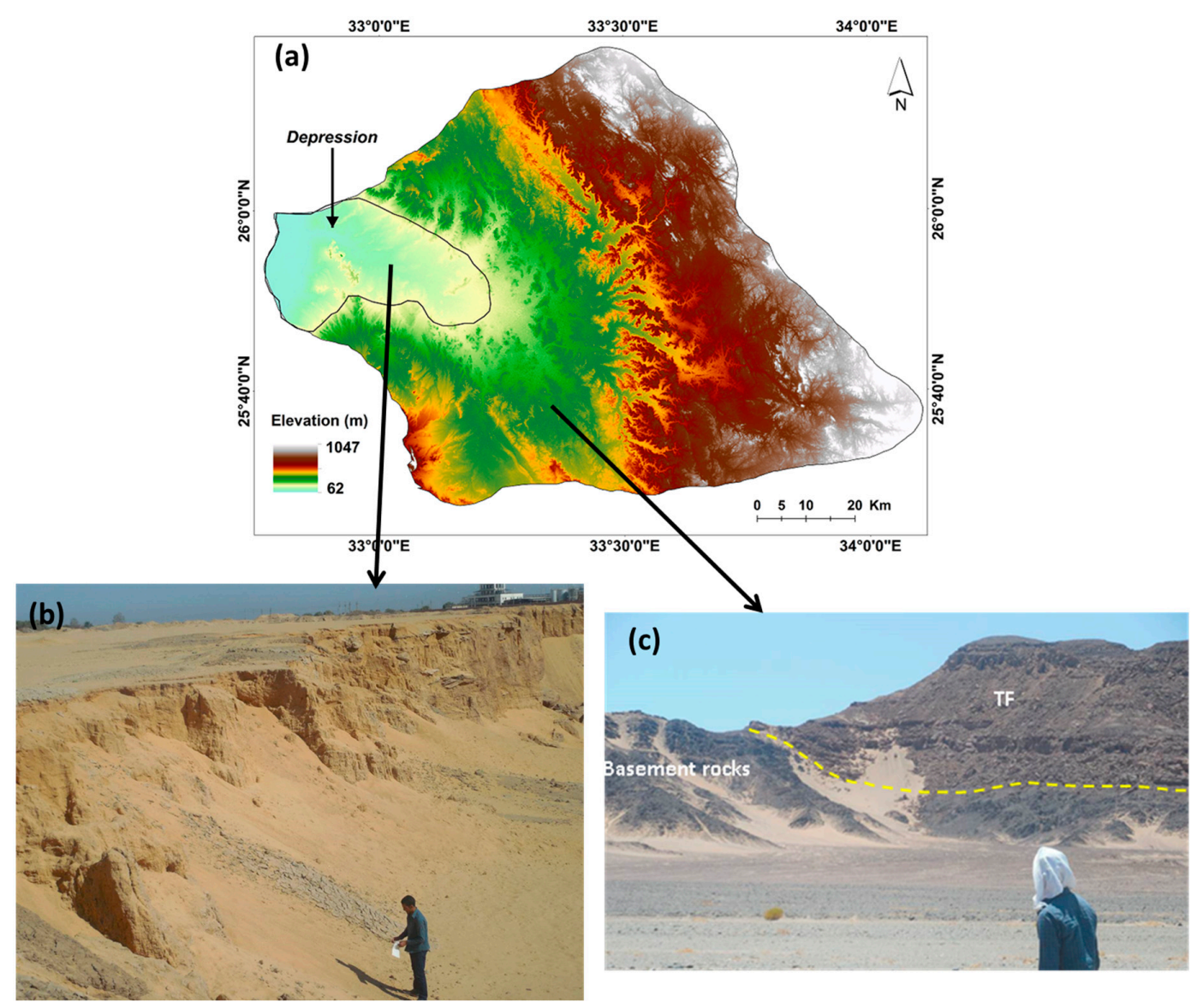

Figure 4. The depression area at the downstream portion of Wadi El-Matulla (a), where the fluvial washed sands are deposited (b) and where its main source rock (Taref Formation (TF)) that capped the basement rocks is located (c).

In this context, the derived CCD maps show clearly low coherence of several parallel and straight lines in the southern eastern part of the Wadi El-Matulla watershed (Figure 6), which were not recognizable on optical images, including high-resolution optical images of Sentinel-2 and Google Earth; however, by closer visual inspection, these lines were found to be linear migrating sand dunes (Figure 7). These linear sand dunes are following the NW-SE direction of the boundary between the sedimentary and crystalline rocks at close proximity. Such dynamic features could not be clearly observed on the change detection maps derived from Sentinel-2 optical data, which is based on changes in optical surface reflectance, as this method cannot detect the temporal decorrelation in either the sand dunes or the wadi deposits during the observed period (Figure 7). Topographically, the highest area in the region is sand-free. Thus, in the Wadi El-Matulla basin, the wind-blown sand emanated from low areas (depressions) located at its downstream reaches and was driven downwind, where it formed several parallel linear sand dunes in a NW-SE direction. These NW-SE linear sand dunes have naturally dammed their parent's stream courses, causing the trapping of surface runoff (flash floods) during the rainy seasons, which led to the formation of lakes (Figure 7). This implies that the sand was originally accumulated at terminal points of rivers and streams, to be later shaped as dunes. 


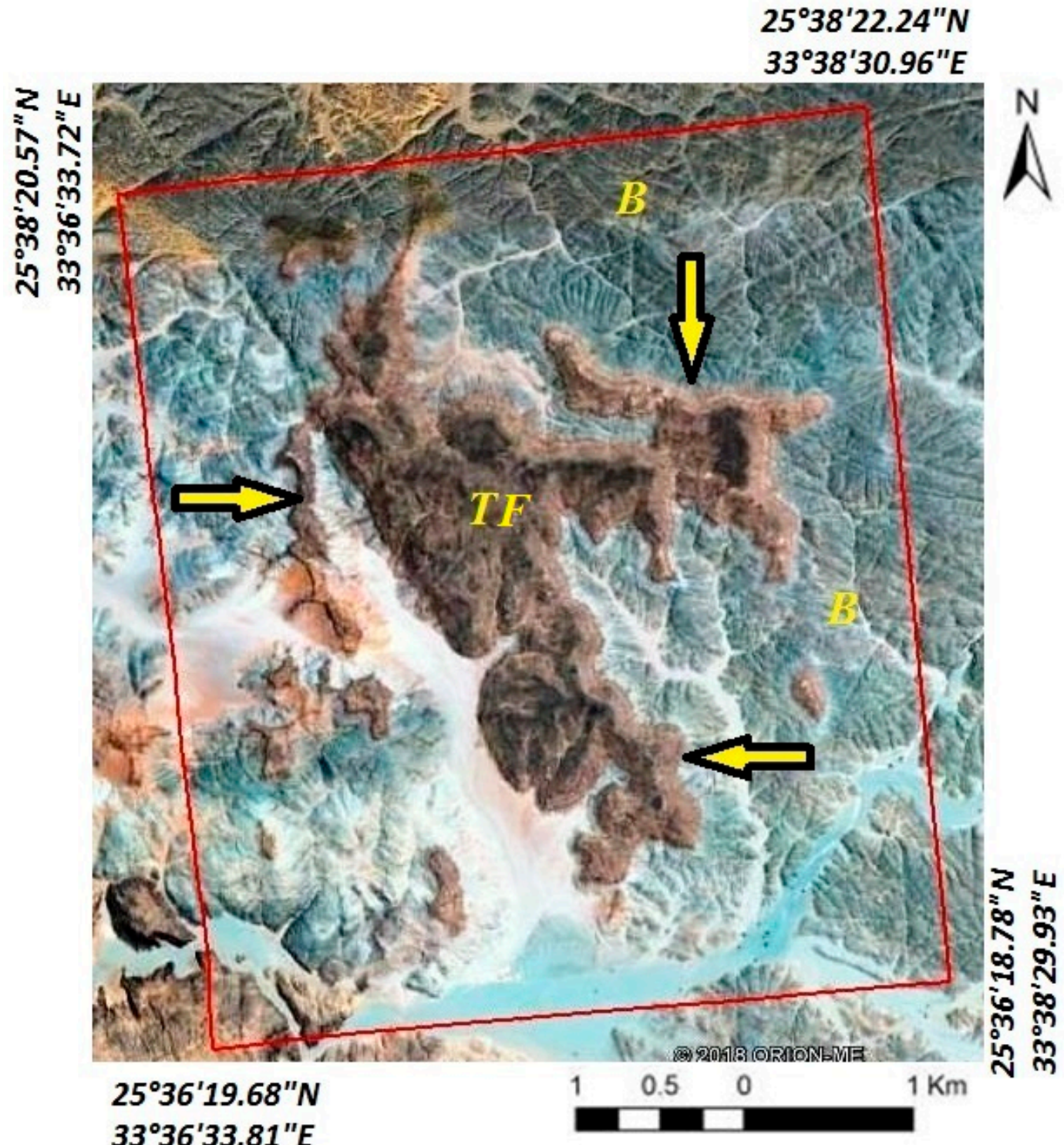

Figure 5. Google Earth image of the remnants of the washed-out Taref Formation (TF), which directly capped the basement (B) rocks and is considered as the main source of the sand deposits in Wadi El-Matulla (the arrows point to these remnants). The spatial distribution of the Taref Formation is depicted in yellow color in Figure 2 and field photographed in Figure 4C.

The El-Gallaba Plain has been subjected to different tectonic events, which have changed its land slope, aspects, the direction of the surface runoff, and thus the depositional direction. In this work, such changes were documented by mapping the tectonomorphic setting of the El-Gallaba Plain from both the SRTM DEM data and aeromagnetic data [67]. The automated extraction of surface drainage patterns in the El-Gallaba Plain shows that this old alluvial fan system has been divided into two separated watersheds (A and B) running in opposite directions, with their outlets pointing directly into the Nile (Figure 8). Watershed A drains toward the north and covers most of the land surface of the El-Gallaba Plain. Its downstream outlet is directly located at the River Nile, very close to Isna City; the second watershed B drains toward the south and its outlet is located at the end of the old stream of Wadi El-Kubbanyia, after having reversed its direction (Figure 8). Moreover, several structure lineaments were digitized from the DEM-derived surface drainage pattern and its watersheds (Figure 8). The main criteria for selecting these structure lineaments were based on the 
straightness of these features: (1) drainage pattern, (2) the boundary of the watersheds, and (3) the water divide between the drainage patterns and their watersheds (Figure 8). In addition, the extensions of these lineaments towards the western calcareous plateau were traced through the outcropped cracks for visual confirmation.

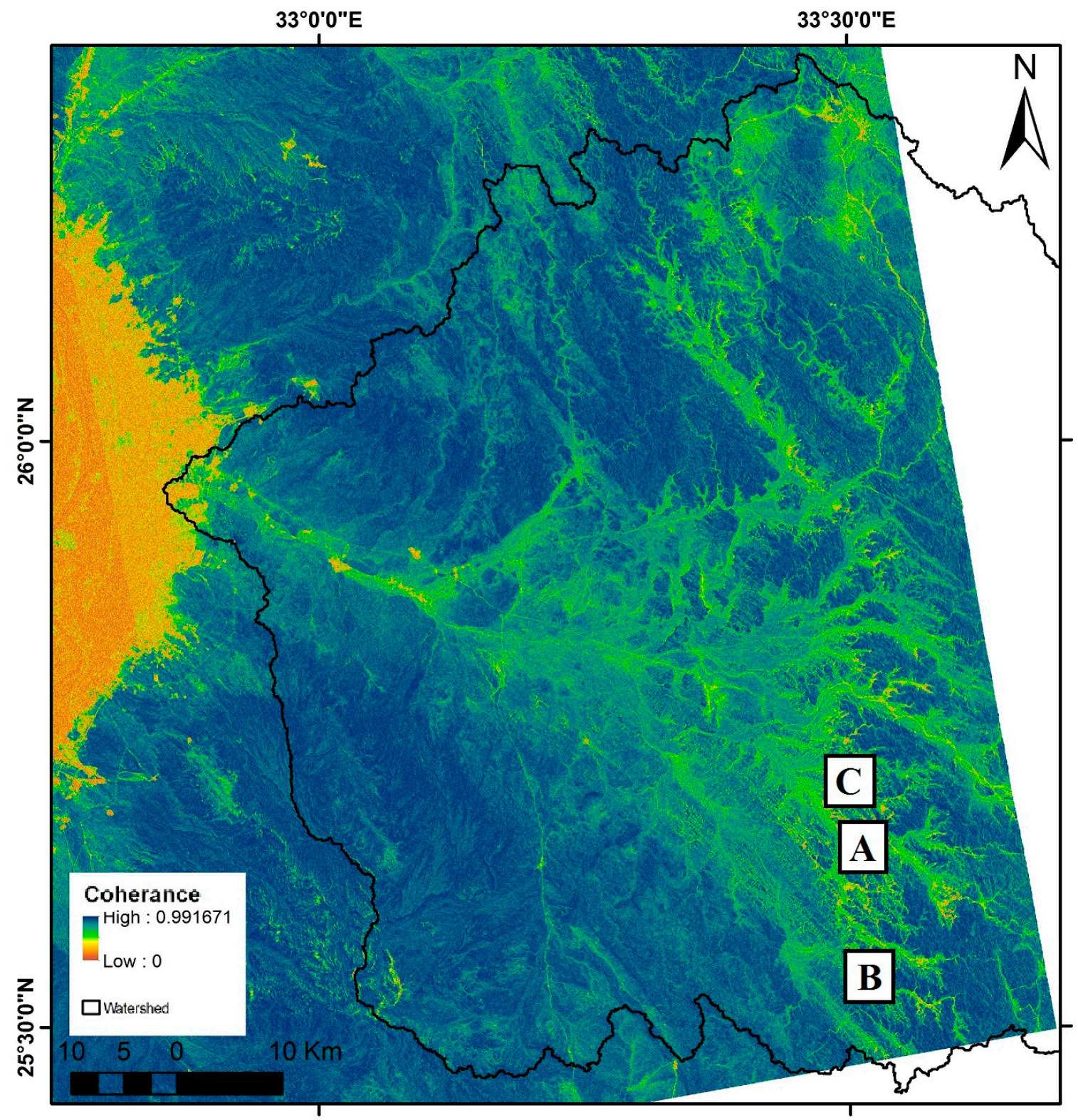

Figure 6. Interferometry Synthetic Aperture Radar (InSAR) coherence images of Wadi El-Matulla show low coherence values close to zero (brown and yellow colors for highly changed areas) and high coherence values close to 1 (blue color for nonchanged areas). The areas A, B, and C are the locations of the zoomed areas in Figure 7. 


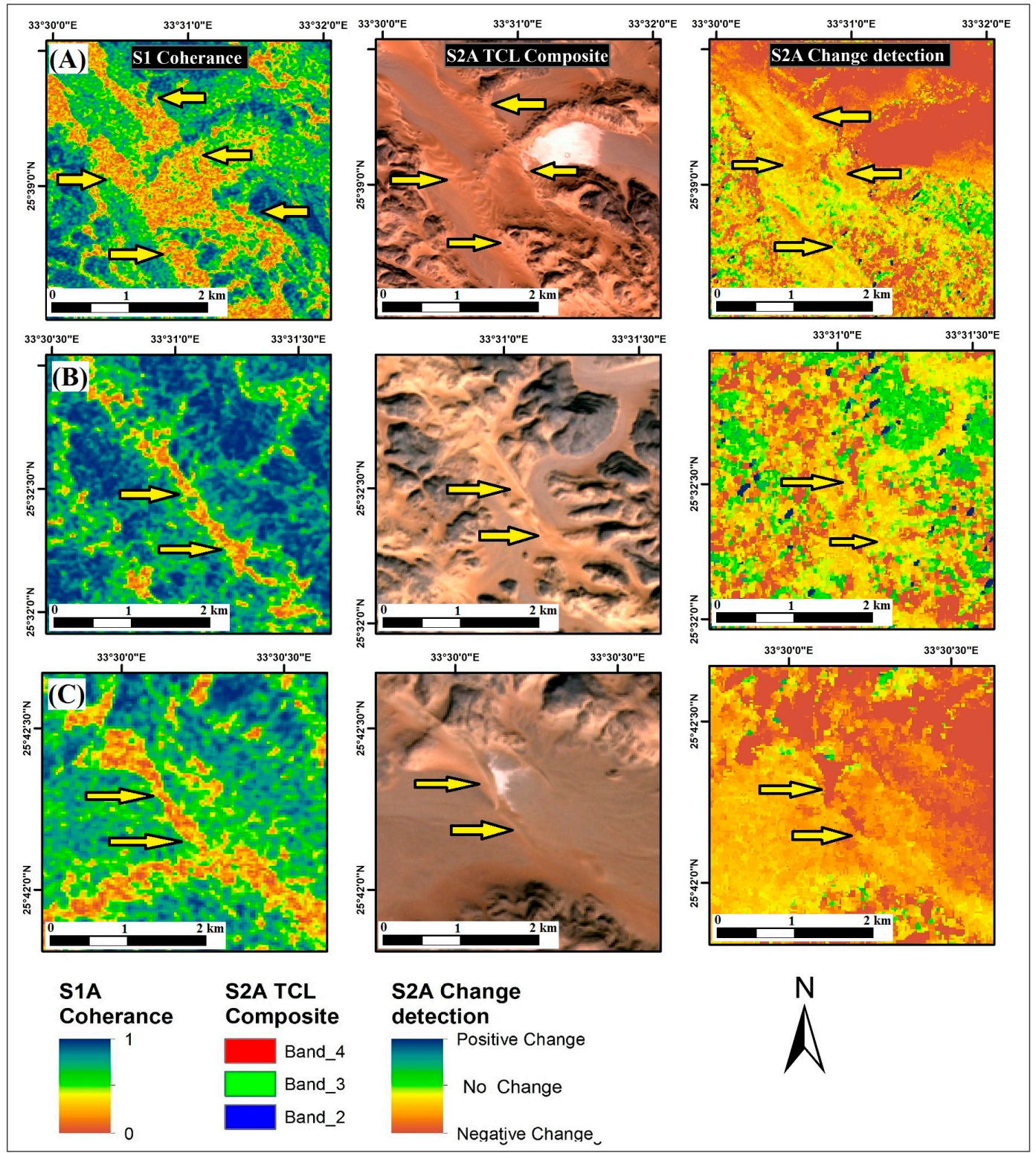

Figure 7. Enlarged InSAR coherence images (left) of Figure 6 (locations A, B, and C), extracted from Sentinel-1 (S1A) data show active linear sand dunes following the NW-SE direction with low coherence values close to zero (brown color) as pointed out by arrows. These linear dunes are damming their parent's streams and forming lakes with white color in the corresponding True Color (TCL) optical Sentinel-2 images (S2A) (middle). However, these features are not clearly detected by the traditional change detection method of the optical Sentinel-2 (S2A) data (right) by subtracting the image of December 2017 from the image of December 2016. 


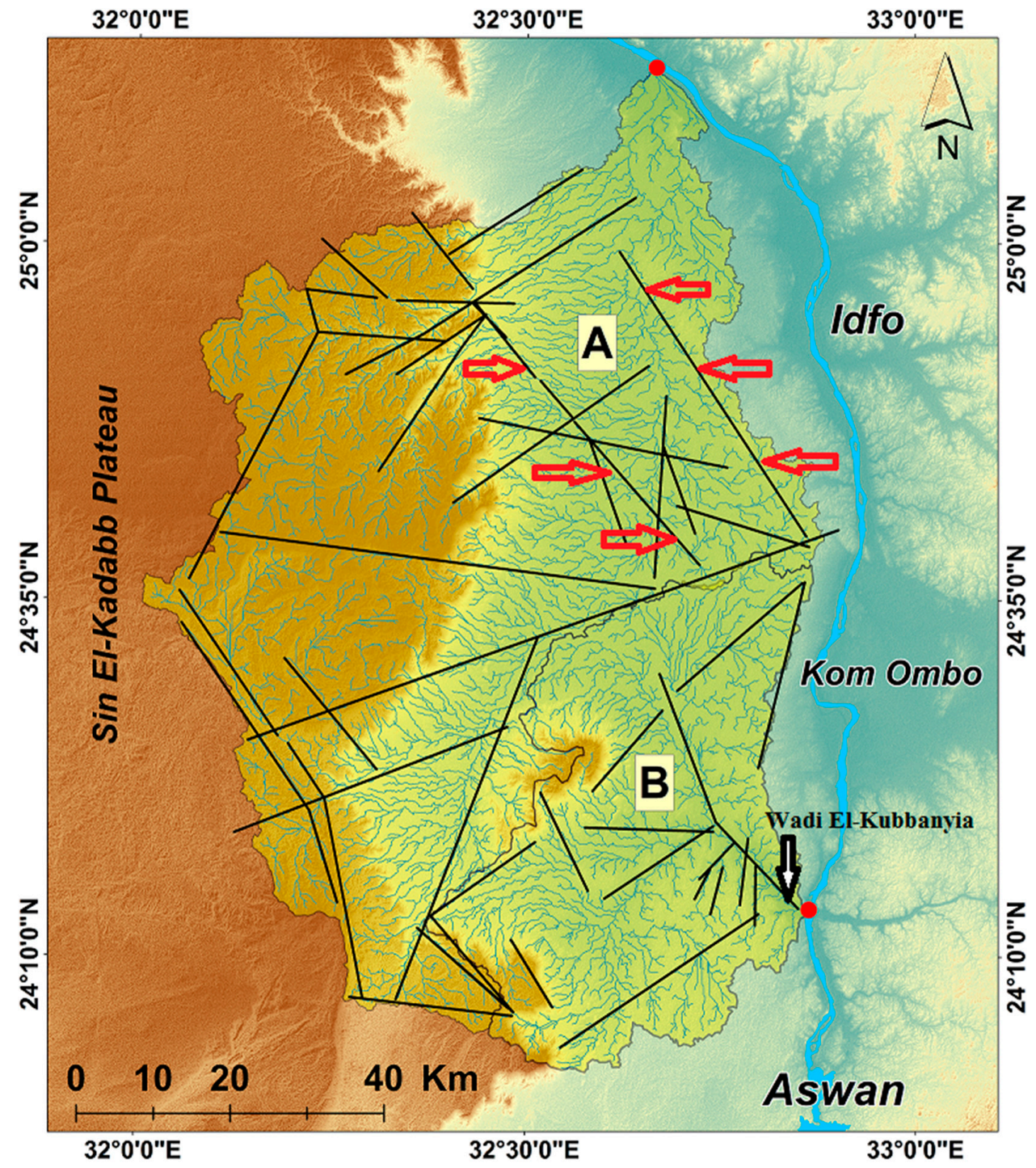

Figure 8. Two distinctive watersheds (A and B) dissect the land surface of the El-Gallaba Plain and drain in two opposite directions ( $\mathrm{N}$ and $\mathrm{S}$ ). The red dots show the outlets of these two watersheds. The black lines represent the extracted lineament features. The red arrows point out the graben, which has been confirmed by the aeromagnetic map of [67]. Such a graben area contains thick quaternary deposits.

\section{Discussion}

Interpretations of features displayed on satellite images and checked in the field have far-reaching implications on the concentration of groundwater resources. Because the sand was transported by paleorivers, the depositional basins would have received vast amounts of fresh water. Much of water would have recharged into the rocks beneath the sands through both primary and secondary porosity. Thus, areas that encompassed large sand accumulations along the selected study area might host vast groundwater resources. Along Wadi El-Matulla, those depressions that are located at the downstream reaches (Figure $4 a, b$ ) and received a huge amount of sand deposits could be good sites for groundwater accumulation.

The low SAR coherence values indicate either natural or anthropogenic changes. The natural changes along the current study area of Wadi El-Matulla are mainly related to changes in the natural vegetation cover along the wadi courses, sand dune encroachment, and active fluvial deposits, while the man-made changes are mainly related to the development of urban infrastructure, agriculture, 
and quarry extensions. By observing the high-resolution Google Earth image and carrying out a field visit, we could confirm that the low SAR coherence values at the northeastern part of the Wadi El-Matulla watershed are mainly related to the growing of natural vegetation and activity in the fluvial deposits during the rainy season. However, at the center of the study area, especially along both sides of the asphaltic road, the low coherence values are related to man-made activities (agriculture and urban developments), while in the southern part of the study area, the low coherence values are mainly related to sand dune encroachment (Figure 6). These observations confirm that the fluvial-eroded and -transported sand particles were deposited downstream of Wadi El-Matulla and later moved toward the southern part of the study area.

In addition, they represent very interesting and unique hydrogeomorphological features, since the linear sand dunes have naturally dammed the southern Wadi El-Matulla courses, forming lakes during the rainy season. These sand-trapped lakes have evaporated later, leaving evaporation ponds (Figure 9).

The white patches in the optical Sentinel-2 and Google Earth images (Figures 7 and 9) represent highly reflective areas (salt efflorescence) which are left by the evaporation of water in the lakes and can be considered as an evidence of surface water accumulation. These white patches are evidence of salt enrichment in the form of salt crusts, covering and filling the surface sediments [68].
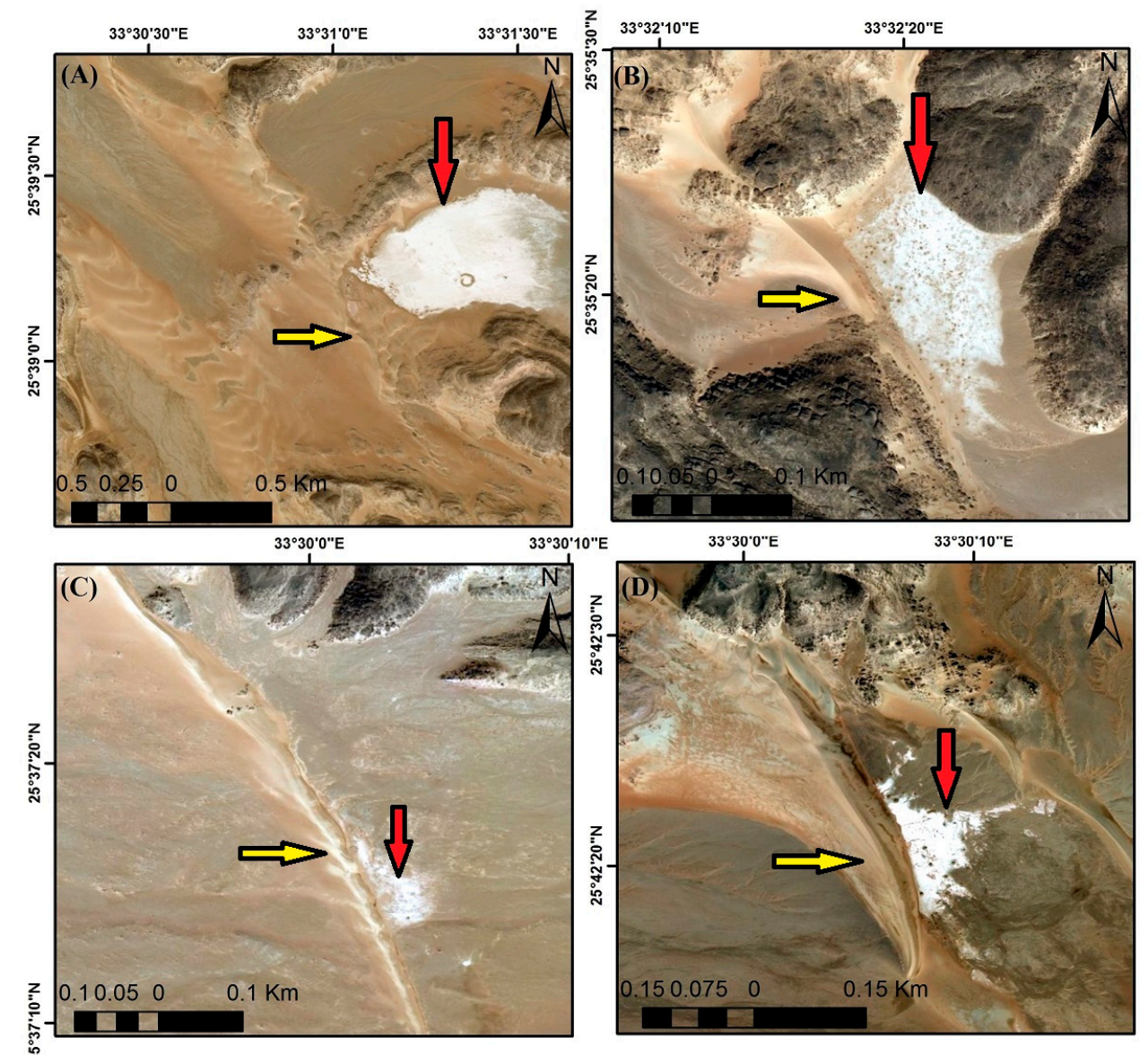

Figure 9. Google Earth images (A-D) of the unique linear dunes (yellow arrows) that naturally dammed its parent's wadi courses and formed freshwater lakes, which appear with white color in the optical images (red arrows) and might be a potential area for groundwater accumulation, in addition to the downstream depression of Wadi El-Matulla, as shown in Figure 4. 
A similar feature was observed in the El-Gallaba Plain basin, located further south of Wadi El-Matulla on the western side of the River Nile. Along the El-Gallaba Plain, the prevailing winds blowing southward reshaped the sand deposits and mainly formed one large linear sand dune field that is controlled by a NW-SE subsurface fault structure [27]. Such a linear dune is very active and is about to totally dam the wadi course of Wadi El-Kubbanyia. The SAR-derived coherence change detection (CCD) image clearly demonstrates the changes (dynamics) along this linear sand dune field (Figures 10 and 11). Large amounts of freshwater may have infiltrated into the underground permeable deposits, and thus, these sites are potentially good prospects for groundwater accumulation and worthy of further exploration using hydrogeophysical methods.

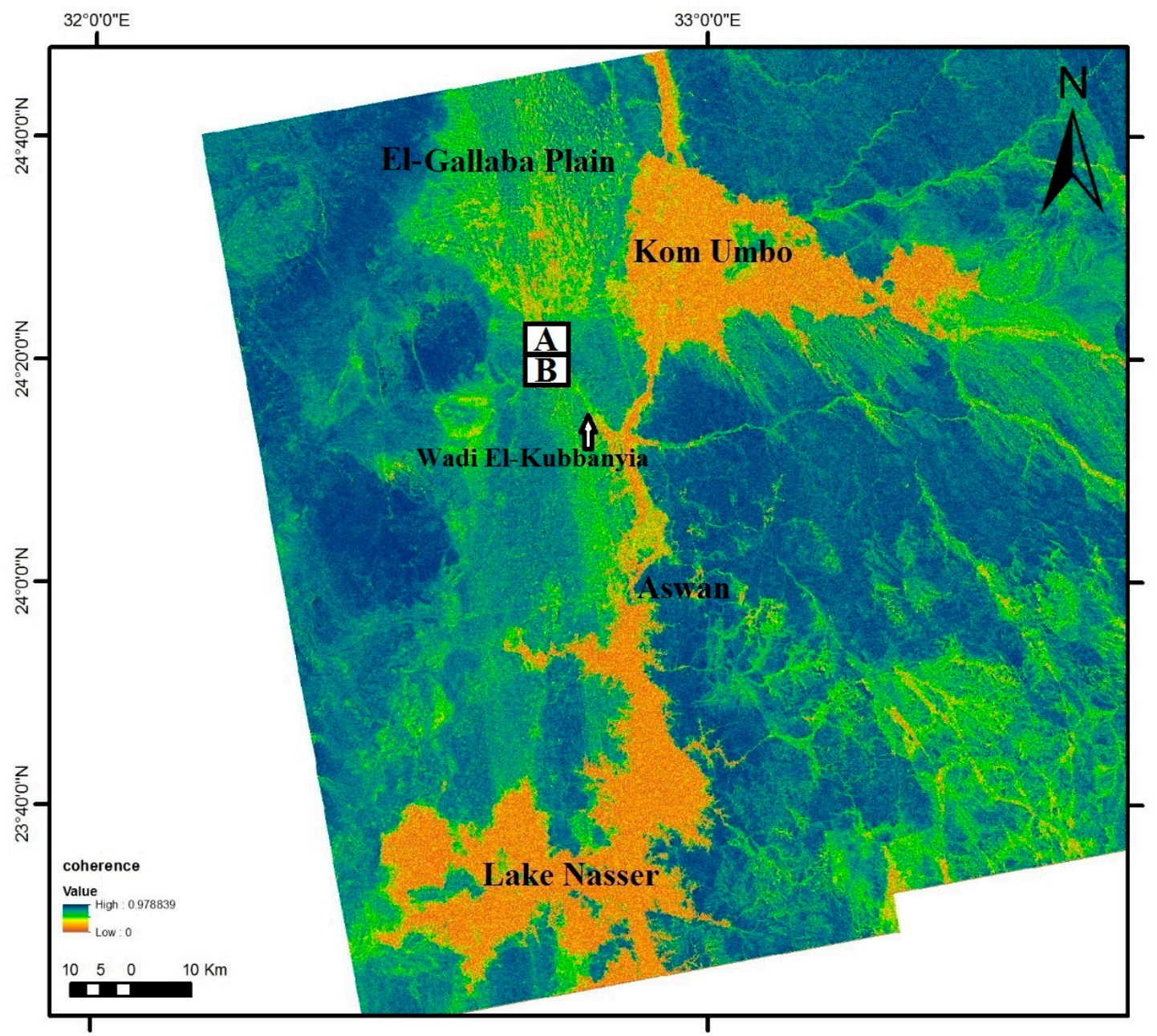

Figure 10. InSAR coherence images of the El-Gallaba Plain, southwest of Wadi El-Matulla, show low coherence values close to zero (brown and yellow colors for highly changed areas) and high coherence values close to 1 (blue color for nonchanged areas). The A and B boxes represent the zoomed-in areas of Figure 11. 

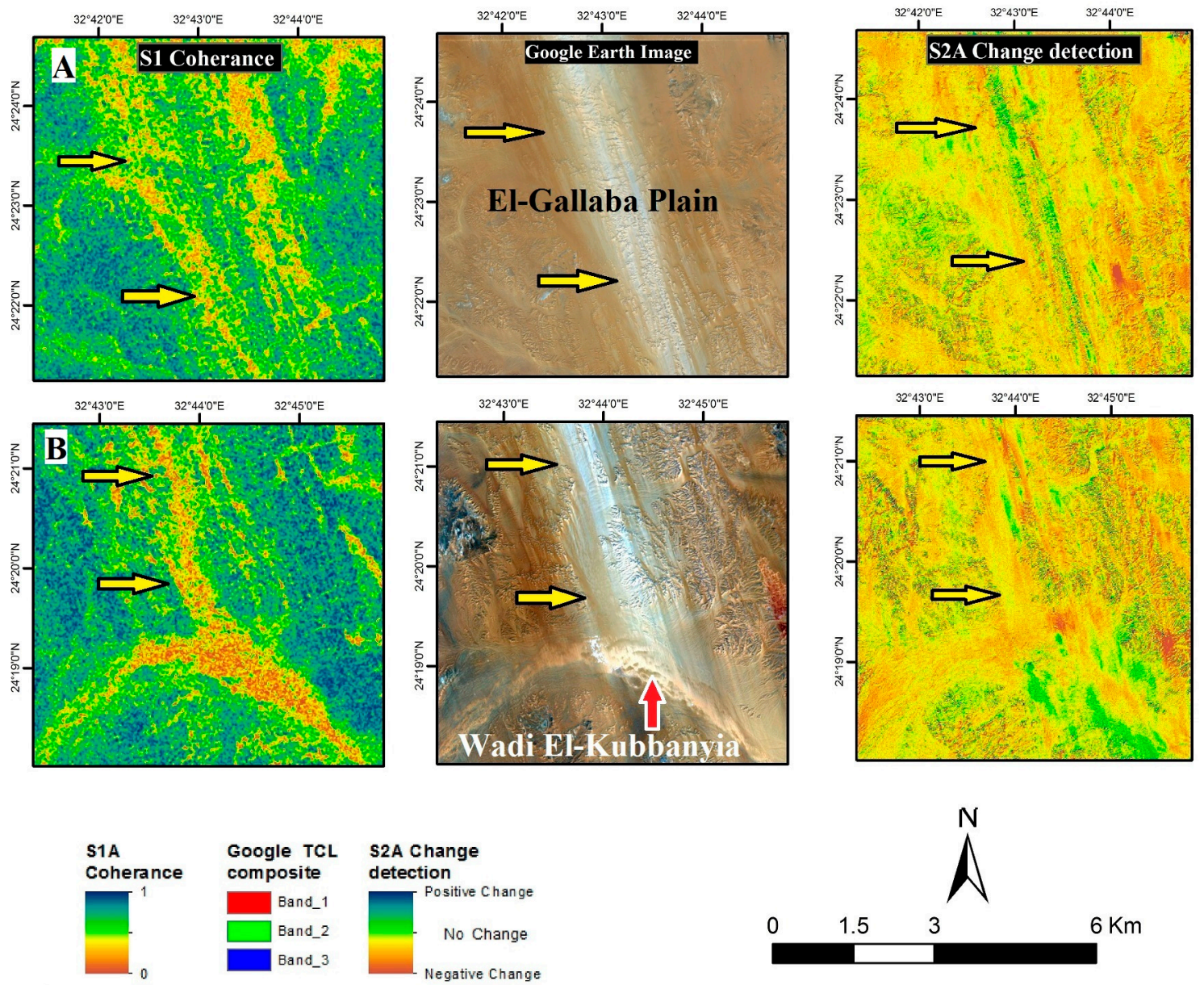

Figure 11. InSAR coherence images (left) of the El-Gallaba Plain show active linear sand dunes (yellow arrows) following the NW-SE direction with low coherence values close to zero (brown color). This linear dune is about to completely trap (dam) its parent's stream of Wadi Kubbanyia (red arrow), similar to what has already occurred in Wadi El-Matulla. The corresponding optical Google Earth image is shown for comparison (middle). The migrating sand dune is very difficult to recognize on the optical Sentinel-2 change detection data (right).

\section{Conclusions}

Interpretations of optical and SAR spaceborne images that provided different levels of information and were obtained at varying scales relate the origin of the sand in the selected test sites in the Eastern Deserts of Egypt (Wadi El-Matulla) to fluvial erosion of the sandstone rocks exposed along its watershed. The automated extraction of surface drainages from the SRTM data suggested the down-gradient transport of the particulate matter along with the water toward the north in the courses of rivers and streams. The latter would have deposited the rounded sand grains within inland depressions at their downstream ends (outlets). Much of the water that accumulated in those depressions-during wet climate episodes in the past-would have recharged through the underlying rock to be stored in primary or secondary porosity as groundwater. When dry climates prevailed, the wind mobilized the sand and shaped it into linear dunes and flat plains. These findings implied that sand was originated by water and sculpted by the wind. It follows that areas with large accumulations of sand might host much groundwater beneath the surface. Moreover, in the current research work, the InSAR CCD, DEM, and optical Sentinel-2 data, together with field observations, were applied to investigate active wind-blown linear dunes that have naturally dammed their parent's wadi courses and formed lakes along Wadi El-Matulla, which is considered to be a unique 
hydrogeomorphological feature and a good site for groundwater accumulation. In addition, the linear dune field at the El-Gallaba Plain will eventually completely dam the eastern part of Wadi El-Kubbanyia by accumulating more sand dunes. Because similar hydrogeomorphic features exist in other deserts, the investigated method might apply to other sandy arid lands worldwide.

Author Contributions: A.G. conceived and designed the manuscript; A.G. and I.S. processed the data and performed the proposed methods; A.G., M.A., M.K., and F.E.-B. interpreted the results; A.G. wrote and M.A., M.K., and F.E.-B. edited the manuscript; A.G. handled the submission steps.

Acknowledgments: The authors would like to thank the European Space Agency (ESA) for providing the Sentinel-1 and Sentinel-2 satellite images as well as SNAP software free of charge. Finally, the authors are very grateful for the very helpful suggestions made by the three reviewers.

Conflicts of Interest: The authors declare no conflict of interest.

\section{References}

1. Ayouty, M.K.; Ezzat, M.A. Hydrogeological observations in the search for underground water in the Western Desert of Egypt. IASH Symp. Athens I 1961, 56, 114-119.

2. Pavlov, M.I. Groundwater of Egypt; Desert Institute, the Hydrology Division, the General Desert Development Organization: Cairo, Egypt, 1962.

3. CEDARE. Nubian Sandstone Aquifer System (NSAS) MEE Rapid Assessment Report; Monitoring \& Evaluation for Water In North Africa (MEWINA) Project, Water Resources Management Program; CEDARE: Cairo, Egypt, 2014; pp. 1-95.

4. Voss, C.; Soliman, S.M. The transboundary non-renewable Nubian aquifer system of Chad, Egypt, Libya and Sudan: Classical groundwater questions and parsimonious hydrogeologic analysis and modelling. In Environmental Geochemistry and Health, with Special Reference to Developing Countries; Appleton, J.D., Fuge, R., McCall, G.J.H., Eds.; Geological Society Special Publication: London, UK, 2014; pp. 163-181.

5. Bagnold, R.A. Journeys in the Libyan Desert. Geogr. J. 1931, 78, 13-39. [CrossRef]

6. Bagnold, R.A. The Physics of Blown Sand and Desert Dunes; Methuen and Company: London, UK, 1941.

7. Sandford, K.S. Geology and Geomorphology of the Southern Libyan Desert. Geogr. J. 1933, 82, $213-219$.

8. Peel, R.F. The Gilf Kebir: Part 4. An Expedition to the Gilf Kebir and Uweinat, 1938. Geogr. J. 1939, 93, $297-307$.

9. Said, R. The Geology of Egypt; Elsevier Publishing Company: Amsterdam, The Netherlands, 1962.

10. Issawi, B. Geology of the Kurkur-Dungul area. Annals of the Geological Survey of Egypt; United States Congress Joint Committee on Printing: Washington, DC, USA, 1968.

11. Issawi, B. New findings in the Gilf-Uweinat area. In Annals of the Geological Survey of Egypt; The Geological Survey of Egypt and Mining Authority: Cairo, Egypt, 1978; Volume 11, pp. 57-66.

12. El-Baz, F. The meaning of desert color in Earth orbital photographs. Photogramm. Eng. Remote Sens. 1978, 44, 69-75.

13. McCauley, J.F.; Schaber, G.G.; Breed, C.S.; Grolier, M.J.; Haynes, C.V.; Issawi, B. Subsurface valleys and geoarchaelology of Egypt and Sudan revealed by radar. Science 1982, 218, 1004-1020. [CrossRef] [PubMed]

14. Elachi, C.; Roth, L.E.; Schaber, G.G. Spaceborne radar subsurface imaging in hyper-arid regions. IEEE Trans. Geosci. Remote Sens. 1984, 22, 383-388. [CrossRef]

15. Schaber, G.G.; McCauley, J.F.; Breed, C.S.; Olhoeft, G.R. Shuttle imaging radar: Physical controls on signal penetration and subsurface scattering in the eastern Sahara. IEEE Trans. Geosci. Remote Sens. 1986, 24, 603-623. [CrossRef]

16. Farr, T.G.; Elachi, C.; Hartl, P.; Chowdhury, K. Microwave penetration and attenuation in desert soil: A field experiment with the Shuttle Imaging Radar. IEEE Trans. Geosci. Remote Sens. 1986, 24, 590-594. [CrossRef]

17. Schaber, G.G.; McCauley, J.F.; Breed, C.S. The use of multifrequency and polarimetric SIR-C/X-SAR data in geologic studies of Bir Safsat, Egypt. Remote Sens. Environ. 1987, 59, 337-363. [CrossRef]

18. Abdelsalam, M.G.; Robinson, C.; El-Baz, F.; Stern, R.J. Applications of orbital imaging radar for geologic studies in arid regions: The Saharan testimony. Photogramm. Eng. Remote Sens. 2000, 66, 717-726.

19. El-Baz, F. Sand accumulation and groundwater in the Eastern Sahara. Episodes 1998, 21, 147-151.

20. Robinson, C.A.; El-Baz, F.; Ozdogan, M.; Ledwith, M.; Blanco, D.; Oakley, S.; Inzana, J. Use of radar data to delineate palaeodrainage flow direction in the Selima sand sheet, Eastern Sahara. Photogramm. Eng. Remote Sens. 2000, 66, 745-753. 
21. Paillou, P.; Grandjean, G.; Baghdadi, N.; Heggy, E.; August-Bernex, T.; Achache, J. Subsurface imaging in south-central Egypt using low-frequency radar: Bir Safsaf revisited. IEEE Trans. Geosci. Remote Sens. 2003, 41, 1672-1684. [CrossRef]

22. Paillou, P.; Reynard, B.; Malézieux, J.-M.; Dejax, J.; Heggy, E.; Rochette, P.; Reimold, W.U.; Michel, P.; Baratoux, D.; Razin, P. An extended field of crater-shaped structures in the Gilf Kebir region-Egypt: Observations and hypotheses about their origin. J. Afr. Earth Sci. 2006, 46, 281-299. [CrossRef]

23. El-Baz, F.; Robinson, C.; Al-Saud, T. Radar images and geomorphology of the eastern Sahara. In Remote Sensing in Archaeology; Wiseman, J., El-Baz, F., Eds.; Springer: New York, NY, USA, 2007; pp. 1-8.

24. Ghoneim, E.; Robinson, C.; El-Baz, F. Radar topography data reveal drainage relics in the eastern Sahara. Int. J. Remote Sens. 2007, 28, 1759-1772. [CrossRef]

25. Paillou, P.; Schuster, M.; Tooth, S.; Farr, T.; Rosenqvist, A.; Lopez, S.; Malézieux, J.M. Mapping of a major paleodrainage system in Eastern Libya using orbital imaging Radar: The Kufrah River. Earth Planet. Sci. Lett. 2009, 277, 327-333. [CrossRef]

26. Paillou, P.; Lopez, S.; Farr, T.; Rosenqvist, A. Mapping Subsurface Geology in Sahara using L-band SAR: First Results from the ALOS/PALSAR Imaging Radar. IEEE J. Select. Top. Earth Obs. Remote Sens. 2010, 3, 632-636. [CrossRef]

27. Gaber, A.; Koch, M.; Helmi, M.; Motoyuki, S. SAR Remote Sensing of Buried Faults: Implications for Groundwater Exploration in the Western Desert of Egypt. Sens. Imaging 2011, 12, 133-151. [CrossRef]

28. Paillou, P. Mapping Palaeohydrography in Deserts: Contribution from Space-Borne Imaging Radar. Water 2017, 9, 194. [CrossRef]

29. Molina, G.; Gaber, A.; El-Baz, F. Mapping palaeolakes as potential areas for groundwater exploration in the Ténéré Desert of northeastern Niger using various space-borne data. NRIAG J. Astron. Geophys. 2017, 6, 395-407. [CrossRef]

30. Gaber, A.; Amarah, B.A.; Abdelfattah, M.; Ali, S. Investigating the use of the dual-polarized and large incident angle of SAR data for mapping the fluvial and aeolian deposits. NRIAG J. Astron. Geophys. 2017, 6, 349-360. [CrossRef]

31. Haynes, C.V. Great Sand Sea and Selima Sand Sheet: Geochronology of desertification. Science 1982, 217, 629-633. [CrossRef] [PubMed]

32. Szabo, B.J.; Haynes, C.V.; Maxwell, T.A. Ages of Quaternary pluvial episodes determined by uranium-series and radiocarbon dating of lacustrine deposits of Eastern Sahara. Paleogeogr. Paleoclimatol. Palaeoecol. 1995, 113, 227-242. [CrossRef]

33. El-Baz, F. Origin and evolution of the desert. Interdisciplin. Sci. Rev. 1988, 13, 331-347. [CrossRef]

34. Abdelsalam, M.G.; Youssef, A.M.; Arafat, S.M.; Alfarhan, M. Rise and demise the New Lakes of the Sahara. Geosphere 2008, 4, 375-386. [CrossRef]

35. Gaber, A.; Soliman, F.; Koch, M.; El-Baz, F. Using full-polarimetric SAR data to characterize the surface sediments in desert areas: A case study in El-Gallaba Plain, Egypt. Remote Sens. Environ. 2015, 162, 11-28. [CrossRef]

36. Lee, H.; Liu, J.G. Analysis of topographic decorrelation in SAR interferometry using ratio coherence imagery. IEEE Trans. Geosci. Remote Sens. 2001, 39, 223-232.

37. Liu, J.G.; Black, A.; Lee, H.; Hanaizumi, H.; Moore, J.M. Land surface change detection in a desert area in Algeria using multi-temporal ERS SAR coherence images. Int. J. Remote Sens. 2001, 22, 2463-2477. [CrossRef]

38. Bodart, C.; Ozer, A. The use of SAR Interferometric Coherence images to study sandy desertification in southeast Niger: Preliminary results. In Proceedings of the 2007 ESA Symposium, Montreux, Switzerland, 23-27 April 2007; pp. 1-5.

39. Bodart, C.; Gassani, J.; Salmon, M.; Ozer, A. Contribution of SAR interferometry (from ERS1/2) in the study of aeolian transport processes: The cases of Niger, Mauritania and Morocco. In Desertification and Risk Analysis Using High and Medium Resolution Satellite Data; Springer: Dordrecht, The Netherlands, 2009; pp. 129-136.

40. Ullmann, T.; Büdel, C.; Baumhauer, P.; Padashi, M. Sentinel-1 SAR Data Revealing Fluvial Morphodynamics in Damghan (Iran): Amplitude and Coherence Change Detection. Int. J. Earth Sci. Geophys. 2016, 2, 7.

41. Havivi, S.; Amir, D.; Schvartzman, I.; August, Y.; Maman, S.; Rotman, S.; Blumberg, D. Mapping dune dynamics by InSAR coherence. Earth Surf. Process. Landf. 2018, 43, 1229-1240. [CrossRef] 
42. Zebker, H.A.; Rosen, P.A.; Goldstein, R.M.; Gabriel, A.; Werner, C.L. On the derivation of coseismic displacement fields using differential radar interferometry-The Landers earthquake. J. Geophys. Res. 1994, 99, 19617-19634. [CrossRef]

43. Massonnet, D.; Feigl, K.L. Radar interferometry and its application to changes in the Earth's surface. Rev. Geophys. 1998, 36, 441-500. [CrossRef]

44. Bürgmann, R.; Rosen, P.A.; Fielding, E.J. Synthetic aperture radar interferometry to measure Earth's surface topography and its deformation. Ann. Rev. Earth Planet. Sci. 2000, 28, 169-209. [CrossRef]

45. Colesanti, C.; Ferretti, A.; Novali, F.; Prati, C.; Rocca, F. SAR monitoring of progressive and seasonal ground deformation using the permanent scatterers technique. IEEE Trans. Geosci. Remote Sens. 2003, 41, 1685-1701. [CrossRef]

46. Blumberg, D.G. Analysis of large aeolian (wind-blown) bedforms using the Shuttle Radar Topography Mission (SRTM) digital elevation data. Remote Sens. Environ. 2006, 100, 179-189. [CrossRef]

47. Ferretti, A.; Monti-Guarnieri, A.; Prati, C.; Rocca, F.; Massonet, D. InSAR Principles-Guidelines for SAR Interferometry Processing and Interpretation; ESA Publications: Noordwijk, The Netherlands, 2007.

48. Embabi, N.S. The Geomorphology of Egypt: Landforms and Evolution. Vol. 1. The Nile Valley and Western Desert; The Egyptian Geographical Society: Cairo, Egypt, 2004.

49. EGSM. Geological Map of Eastern Desert, Egypt. Scale 1:500,000; The Egyptian General Petroleum Corporation: Cairo, Egypt, 1987.

50. Conoco. Geological Map of Egypt, Scale 1:500,000, Sheet NG36NE Quseir, NG36NW Asyut, NG36SE Gebel Hamata, and NG36SW Luxor, Egypt; The Egyptian General Petroleum Corporation: Cairo, Egypt, 1987.

51. El-Baz, F.; Mainguet, M.; Robinson, C. Fluvio-aeolian dynamics in the north-eastern Sahara: The relationship between fluvio/aeolian systems and groundwater concentration. J. Arid Environ. 2000, 44, 173-183. [CrossRef]

52. Koch, M.; Gaber, A.; Gereish, M.; Zaghloul, S.; Arafat, S.; AbuBakr, M. Multisensor Characterization of Subsurface Structures in a Desert Plain Area in Egypt with Implications for Groundwater Exploration. Proc. SPIE 2013, 8887. [CrossRef]

53. Roth, L.E.; Elachi, C. Coherent Electromagnetic Losses by Scattering from Volume in Homogeneities. IEEE Trans. Antennas Propag. 1975, 23, 674-675. [CrossRef]

54. Elachi, C.; Brown, W.E.; Cimino, J.B.; Dixon, T.; Evans, D.L.; Ford, J.P.; Saunders, R.S.; Breed, C.; Masursky, H.; McCauley, J.; et al. Shuttle imaging radar experiment. Science 1982, 218, 996-1003. [CrossRef] [PubMed]

55. Gaber, A.; Koch, M.; Gereish, M.; Motoyuki, S.; El-Baz, F. Near-Surface Imaging of a Buried Foundation in the Western Desert, Egypt, Using Space-borne and Ground Penetrating Radar. J. Archaeol. Sci. 2013, 40, 1946-1955. [CrossRef]

56. Touzi, R.; Lopez, A.; Bruniquel, J.; Vachon, P.W. Coherence Estimation for SAR Imagery. IEEE Trans. Geosci. Remote Sens. 1999, 37, 135-149. [CrossRef]

57. Preiss, M.; Stacy, N.J. Coherent Change Detection: Theoretical Description and Experimental Results (No. DSTO-TR-1851); Defence Science and Technology Organization: Edinburgh, Australia, 2006.

58. ESA. Copernicus Sentinel-1 and Sentinel-2 Satellite Data. Available online: https:/ / scihub.copernicus.eu/ dhus/\#/home (accessed on 24 May 2018).

59. Jenson, S.; Dominique, J. Extracting topographic structure from digital elevation data for geographical information system analysis. Photogramm. Eng. Remote Sens. 1988, 54, 1593-1600.

60. El Bastawesy, M.; Faid, A.; El Gammal, S. The quaternary development of tributary channels to the Nile River at Kom Ombo area, Eastern Desert of Egypt, and their implication for groundwater resources. Hydrol. Process. 2010, 24, 1856-1865. [CrossRef]

61. Abdalla, F. Mapping of groundwater prospective zones using remote sensing and GIS techniques: A case study from the Central Eastern Desert, Egypt. J. Afr. Earth Sci. 2012, 70, 8-17. [CrossRef]

62. Sandford, S.K. The Pliocene and Pleistocene deposits of Wadi Qena and of the Nile Valley between Luxor and Assiut (QAU). Q. J. Geol. Soc. 1929, 85, 493-548. [CrossRef]

63. Mainguet, M.M. L'homme et la Secheresse; Collection Geographique: Mason, Paris, 1995.

64. El-Baz, F.; Wolfe, R.W. Wind Patterns in the Western Desert; NASA Scientific and Technical Information Branch, CR-3611: Washington, DC, USA, 1982; pp. 119-139.

65. Hereher, M. Assessment of sand drift potential along the Nile Valley and Delta using climatic and satellite data. Appl. Geogr. 2014, 55, 39-47. [CrossRef] 
66. Mainguet, M.M.; El-Baz, F. Effects of topography on dune orientation in the Farafra region, Western Desert of Egypt and implications to Mars. NASA Tech. Memo 1980, 82385, 298-300.

67. Mo'men, A.; Darwish, M.; Abdelhady, A.; Essa, M.A. Structural and Lithostratigraphic evolution of Al Baraka Oil field, Komombo Basin, Upper Egypt as deduce from 2D seismic lines and well logging data. J. Basic Environ. Sci. 2017, 2, 149-169.

68. Schmid, T.; Koch, M.; Gumuzzio, J. Application of hyperspectral imagery to map soil salinity. In Remote Sensing of Soil Salinization: Impact and Land Management; Metternicht, G., Zinck, A., Eds.; CRC Press, Taylor and Francis Publisher: Boca Raton, FL, USA, 2009; Chapter 7; pp. 113-139.

(C) 2018 by the authors. Licensee MDPI, Basel, Switzerland. This article is an open access article distributed under the terms and conditions of the Creative Commons Attribution (CC BY) license (http:/ / creativecommons.org/licenses/by/4.0/). 